\title{
LEVELEZÉS BACSÁK GYÖRGY ÉS MILUTIN MILANKOVIĆ KÖZÖTT
}

\section{THE MILUTIN MILANKOVIĆ AND GYÖRGY BACSÁK CORRESPONDENCE}

\author{
Hágen András \\ független kutató, Arany János Általános Iskola, Felsőszentiván \\ hagena@freemail.hu \\ „Az elméleti számítások tehát olyan jól vágnak \\ a természet megfigyelés eredményeivel, \\ hogy Milankovitch elméletében kételkedni nem lehet."
}

Bacsák György, 1940

\section{ÖSSZEFOGLALÁS}

Bacsák György magyar polihisztor 150 éve született és 50 éve halt meg. Jelentős szerepe volt a Milanković-ciklus pontosításában és továbbfejlesztésében. A Milanković-elmélet a Föld mozgásaiban bekövetkező változásoknak az éghajlatra gyakorolt hatását írja le. Az elmélet a kidolgozójáról, Milutin Milanković szerb geofizikusról és csillagászról kapta a nevét. A szerb tudóst az I. világháború idején az Osztrák-Magyar Monarchia hatóságai ellenséges állam polgáraként internálták. A Magyar Tudományos Akadémia könyvtárában dolgozta ki elméletét. Az elmélet lényegének megértése érdekében Bacsák György 1938 és 1955 között rendszeres levelezés formájában élvezte Milanković elvi támogatását. Összességében Bacsák György 56 levelet írt Milutin Milankovićnak, míg a szerb tudós 10 levelet írt, amelyek mind fellelhetők a Magyar Tudományos Akadémia Könyvtárában. A levelek nyelve német volt, mivel mind Bacsák, mind Milanković folyékonyan beszélt németül. E levelezésre épült Bacsák György 1940-ben megjelent három cikke az Időjárás folyóiratban, valamint 1944-ben megjelent könyve Az utolsó 600000 év földtörténete egy részlete is.

\section{ABSTRACT}

György Bacsák, a Hungarian polymath, was born 150 years ago and died 50 years ago. He played an important role in refining and further developing the Milanković cycle. Milanković's theory describes the effect of changes in Earth's movements on the climate. The theory came from its creator, Milutin Milanković, a Serbian geophysicist and astronomer. The Austro-Hungarian Monarchy during the First World War interned the Serbian scientist as the national of an enemy state. He developed his theory in the library of the Hungarian Academy of Sciences. Understanding the essence of the theory, György Bacsák enjoyed the theoretical support of Milanković in the form of regular correspondence between 1938 and 1955. In total, György Bacsák wrote 56 letters to Milutin Milanković, while the Serbian scholar wrote 10 letters, all of which can be found in the Library of the Hungarian Academy of Sciences. The language of the correspondence was Ger- 
man, since both Bacsák and Milanković spoke German fluently. Three 1940 articles from György Bacsák published in the Hungarian journal Weather and a part of his 1944 book, Earth's History of the Last 600,000 Years, were based on this exchange of letters.

Kulcsszavak: Milutin Milanković, Bacsák György, levelezés, interglaciálisok, interferenciák

Keywords: Milutin Milanković, György Bacsák, letter exchange, interglacial, interference

\section{BEVEZETÉS}

A 19. században a geológusok kezdték felismerni, hogy az elmúlt évezredekben több eljegesedés is történt. Uralkodóan az eljegesedések Skandináviából indultak ki, és egészen az Alpok déli lábáig húzódtak. Mivel az Alpok hegygerincein a jégkorszakok nyomai jobban elkülönültek, mint az északi síkvidékeken, így neveik az ottani jelekből származnak. Az elmúlt 600000 év alatt négy nagy jégkorszak volt, amelyek mindegyikében több eljegesedési csúcs volt. A legnagyobb eljegesedéskor a jégtakaró a Föld felszínének 9\%-át foglalta el. Napjainkban az állandó jégtakaró 3\%-nyi.

A 19. század kutatói tanácstalanul álltak a probléma előtt, mert sokáig azt hitték, hogy Földünk éghajlata állandó volt, mivel az írott történelem erröl tanúskodik.

A 20. század elején a kutatók arra a megállapításra jutottak, hogy sok köbkilométer jég felhalmozódásához nem általános lehủlés, hanem enyhe telek és hűvös nyarak évezredeken át tartó folyamatos előfordulása, azaz az évszakok közötti különbségek csökkenése vezetett. Mivel az évszakokat a Föld forgástengelye és a Nap körüli keringés síkja által bezárt szögnek a merőlegestől való eltérése okozza, ezért a forgástengely irányának változásában lehet keresni az eljegesedések magyarázatát. A Föld Nap körüli keringési pályaelemeinek változását pedig a többi bolygó zavaró gravitációs hatása okozza.

\section{MILANKOVIĆ-BACSÁK-CIKLUS}

Ezen okok keresésébe kezdett bele a Belgrádi Egyetemen Milutin Milanković. 1914 nyarán éppen az Osztrák-Magyar Monarchia területén tartózkodott, amikor kitört az I. világháború, és mint az ellenséges Szerbia állampolgárait őt és feleségét a Monarchia hatóságai internálták. Kapcsolatai révén hamarosan Budapestre került, ahol a Magyar Tudományos Akadémia Könyvtárában (1. ábra), valamint a matematikai osztályon tovább folytatta kutatását.

A világháború második évében már nagyjából elkészült a monográfiájával. Arra számított, hogy a háború hamarosan véget ér, és publikálhatja munkáját. A kataklizma elhúzódott, így csak 1920-ban publikálhatta munkáját francia nyelven. Szerinte a csillagászati ritmusszabályozásnak három összetevője van: 


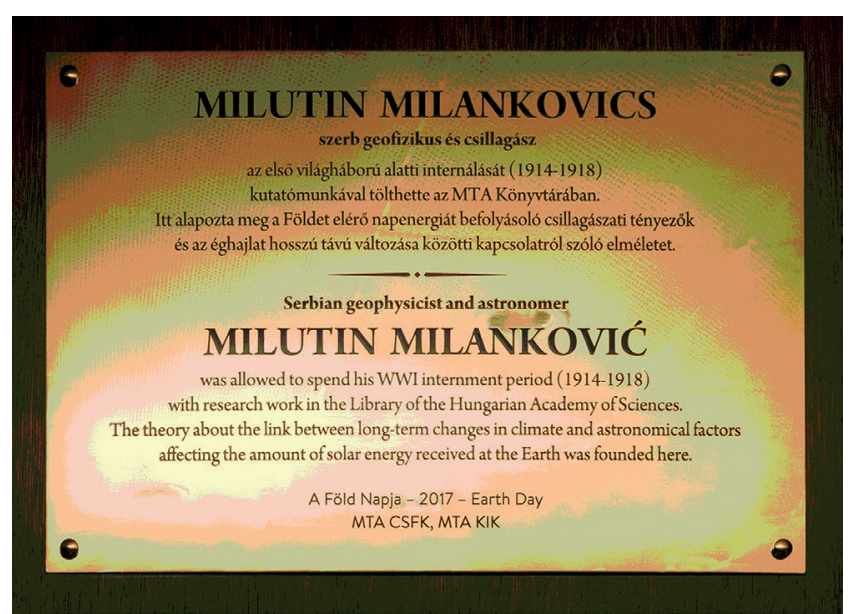

1. ábra. A Milutin Milanković tiszteletére a Magyar Tudományos Akadémia Könyvtárában 2017. április 20-án elhelyezett emléktábla

(Fotó: Szigeti Tamás, mta.hu)

Az első a Föld forgástengelyének hajlásszöge. A forgástengely iránya jelenleg $23,5^{\circ}$-os szöget zár be a Föld keringési síkjára állított merőlegessel. Ez a szög 41000 éves periódussal ingadozik $21,5^{\circ}$ és $24,5^{\circ}$ fok között. Minél nagyobb a hajlásszög, annál szélsőségesebbek az évszakok mindkét félgömbön: a nyarak melegebbek, a telek pedig hidegebbek.

A második összetevő a Föld pályájának alakja, amely 100000 éves periódussal változik. Egyszer megnyúlik, és nagy excentricitású ellipszis alakját ölti, majd ismét szinte kör alakúvá válik. Ha nő az excentricitás, akkor nő a különbség a Nap és Föld legkisebb és legnagyobb távolsága között. Jelenleg a Föld akkor távolodik el legjobban a Naptól, amikor a déli félgömbön tél van, ennek következtében a déli félgömbön a tél valamivel hidegebb, a nyár viszont valamivel melegebb, mint az északi félgömbön.

A harmadik összetevő a precesszió, vagyis a Föld forgástengelyének - a Nap és a Hold által a Földre gyakorolt forgatónyomaték hatására bekövetkező - elmozdulása. A forgástengely 23000 év alatt ír le egy teljes kört a csillagokhoz képest. A precesszió határozza meg, hogy egy adott félgömbön a nyár a földpálya napközeli vagy naptávoli pontjára esik-e, vagyis, hogy a Föld éghajlatának a tengely ferdesége miatti évszakosságát erősíti vagy gyengíti-e a pálya excentricitásából adódó évszakosság. Ha az évszakosság e két meghatározója (a tengelyferdeség és pályaexcentricitás) az egyik félgömbön szinkronban van egymással, akkor az ellentétes félgömbön aszinkronban kell lennie. Tehát a két pólus térségére vetítve az eljegesedési ciklusok ellentétesek. 
Milanković kiszámította, hogy e három tényező együttes hatására a nyári napsugárzás mennyisége az északi sarok közelében akár 20\%-kal is változik. Ez pedig elegendő ok lehet az északi félteke szárazföldjének északi részét borító jégmező előrenyomulására, amikor hủvös nyarak és enyhe telek váltogatják egymást.

A szerb tudós kutatásait rendszerezte és egy táblázatban foglalta össze. Milanković táblázatában a felsorolt 9 eljegesedési csúcsra koncentrált, amelyek összes ideje a 600000 éves időszak hatodát sem tette ki, és a nagyobb részt kitöltő interglaciálisokra - az eljegesedések közötti időszakokra - nem fordított figyelmet.

Az elmélet legelső megértője, magyarázója és alkalmazója a kiváló matematikai érzékekkel megáldott Bacsák György lett, aki maga nem vett részt az elmélet kidolgozásában. Bacsák nevéhez alapvetően az interglaciálisok vizsgálata, valamint a pontos matematikai apparátus alkalmazása füzhető. Így keletkezett a magyar nyelvterületen használt Milanković-Bacsák-ciklus elnevezés, ugyanis globálisan csak Milanković-ciklusnak hívják.

Milanković elméletét azért kellett magyarázni, mert soha nem írta le kellő részletességgel az elmélet csillagászati és égi mechanikai alapjait, amelyhez a számításokat egyik munkatársa, Vojislav Misković végezte. Másrészt Milanković elég nehézkesen fogalmazott, ezért lehetőséget adott félreértésekre.

\section{BACSÁK GYÖRGY}

A neves magyar tudós Pozsonyban született 1870 -ben, itt végezte iskoláit német nyelven, majd jogászdoktori oklevelet szerzett a budapesti Pázmány Péter Tudományegyetemen. Az I. világháborút követően először a Fejér megyei Hörcsökre, majd a Somogy megyei Fonyódra került.

Idejének jó részét a városoktól távol töltötte fonyódi villájában. Mindig korán kelt, későn feküdt, és tisztában volt azzal, hogy az elmélyült szellemi tevékenységnek elengedhetetlen kiegészítője az intenzív fizikai munka és a megfelelő sport. Ezt a frissítő kurzust naponta gyakorolta is (Gádoros, 1970).

Autodidakta módon sajátította el a csillagászati ismereteket, amelyek, kiegészülve széles matematikai ismereteivel, jelentős szerepet játszottak abban, hogy megismerje és alkalmazza Milutin Milanković elméletét az éghajlatváltozások égi mechanikájáról. Sajnálatosan már nagyon későn - hetvenévesen - publikálta eredményeit az éghajlatváltozásról. A Magyar Tudományos Akadémia felkérésének engedelmeskedve 1954-ben, 85 évesen (!) nyújtotta be disszertációját a jégkorszakok keletkezésének okairól. A dolgozatát olyan sikeresen védte meg, hogy megkapta a földtudományok doktora címet.

Bacsák nemcsak a jégkorszakok kutatásában nyújtott maradandót, hanem Fonyód régészeti emlékeinek feltárásában és megmentésében is. 
A híres magyar polihisztor hosszú időt élt meg, talán sportszeretetének vagy derüs természetének köszönhetően, ugyanis századik születésnapja elött három hónappal, 1970. március 4-én halt meg.

Bacsák Györgyre nagy tisztelettel emlékezik a Magyarhoni Földtani Társulat és a Magyar Földrajzi Társulat is. E két szervezet emléktáblát helyezett el a tudós fonyódi házán (2. ábra). A Magyar Tudományos Akadémia Földtudományi Osztálya 1997-ben emlékülést tartott a tiszteletére.

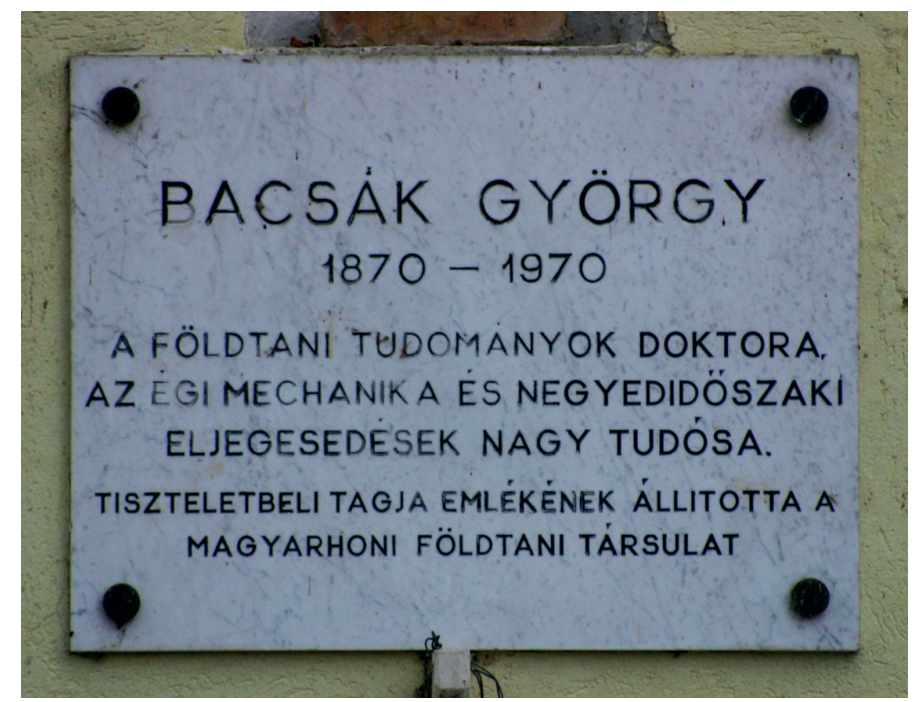

2. ábra. Emlékezés Bacsák Györgyre Fonyód városban

(Fotó: Varga István, 2019)

A következőkben ismerkedjünk meg azzal a három levéllel, amellyel beírta nevét a paleoklimatológiai kutatások történetébe.

\section{RÉSZLETEK BACSÁK GYÖRGY 1938-AS LEVELÉBŐL}

Bacsák György 1938 és 1955 között élvezte Milanković elvi támogatását rendszeres levelezésük formájában. Összességében Bacsák György 56 levelet írt Milutin Milankovićnak, míg a szerb tudós 10 levelet írt, amelyek mind fellelhetők a Magyar Tudományos Akadémia Könyvtárában. A levelek nyelve német volt, mivel mind Bacsák, mind Milanković folyékonyan beszélt németül.

Bacsák 1938-ban írt levelében fellelhető egy későbbi publikációjának vázlata is. „Amikor 1933-ban olvastam az Ön klasszikus müvét a »Matematische Klimalehre und astronomische Theorie der Klimaschwankungen«-t, és mondaniva- 
lóját felfogtam, akkor a figyelmemet rögtön Misković táblázatára irányítottam, és izgatottan vártam a Guttenbergi geofizika 8. kötetének megjelenését, ahol az Ön megjegyzései alapján a 124. oldalon jobb megközelítést reméltem. A mai napig nem sikerült ezt a könyvet beszereznem. Azonban sikerült a Királyi Szerb Akadémián keresztül beszereznem a CLIII. füzetét, ami alapján kiderült, hogy helyesek a megérzéseim arról, hogy a delta értéke a 13. táblázatban szereplő 465 és 465,4 (t) időnél használt -0,0234 és -0,0239 értékek hibásak..."

Bacsák felhívta Milanković figyelmét a nyomdai tévedésre, amiért cserébe azt kérte, hogy a szerb professzor vizsgálja meg Bacsák kérdéseit, és igyekezzen azokra választ is adni.

„Ha mi $\varepsilon$ (a Föld forgástengelye) és e $\sin \pi$ (precesszió) görbéit a megfelelő részeken a grafikus 13. táblázat alapjaira helyezzük, és a kapott koordinátáit öszszeadjuk, megkapjuk a görbét, amely a kisebb inverziójával egyetemben hasonló a II. táblán ábrázolt görbékkel. Mivel mi európai archeológusok vagyunk, ezért minket elsősorban a kritikus geografikus részek érdekelnek az Alpok és Skandinávia között, ezért talán megengedhető számunkra, hogy ezt az egyetlen éghajlati görbét kalendáriumként használjuk."

A kalendáriumot követően Bacsák György inkább az interglaciálisok irányába fordult. Így a második kérdése már sokkal inkább kapcsolódott a jégkorszakok közéhez.

„Kizárólagosan jégkorszakokkal semmiféleképpen nem tudunk rendet teremteni az archeológusok kronológiájának borzalmas dzsungelében. Azonban egyértelmúen segítséget nyújtana számunkra, ha az interglaciális részekkel foglalkoznánk az éghajlati stádiumokban. Ezt én erősen sematikusan a következőképpen képzelem el:

E képletet, $\Delta$ (e $\sin \pi)$ [a precessziót] minden más elé helyezném, hogy az évszakok közötti ellentétek 21000 éves ritmicitást mutassanak. Eközben $\varepsilon$ [a Föld forgástengelyének hajlásszöge] szerepe marad, miszerint az átlaghőmérséklet 40000 évenként emelkedik és süllyed. Következésképpen a klímaváltozás e két tényező interferenciájától függ és a következő négy klímatípust hozza létre:

1. A két görbe interferenciája az alsó kulminációkon a jégkorszakokat hozza létre (rövid, nedves, kellemes tél, hosszú, hűvös nyár).

2. A két görbe interferenciája a felső kulminációkon egy jégkorszakközi klímát mutat (hosszú, száraz, enyhe tél, rövid, forró nyár), mint ahogy 10000 , $85000,175000 \mathrm{stb}$. éve volt.

3. Az interferencia $\Delta \varepsilon$-nek a felső kulmináción és a $\Delta(\sin \pi)$ alsó kulmináción egy szubtrópusi klímát mutat (nedves, rövid, kellemes tél, hosszú, forró nyár), pl. 47 000, 95000,210000 stb. éve volt.

4. Az interferencia $\varepsilon$-nak alsó kulmináción és a $\Delta(\sin \pi)$ felső kulmináción egy szubtropikus klímát ad ki (nedves, hosszú, hủvös tél, mérsékelt, rövid nyár), pl. $150000,270000,310000$ stb. éve." 
Minthogy a $\Delta \varepsilon$ és a $\Delta$ (e sin $\pi$ ) értékei a földrajzi szélességektől függetlenek, így el lehet készíteni egy kalendáriumot, majdnem minden szélességi fokra, valamint a déli féltekére is (3. ábra).

Diltviklis kalendkritm.

Diluvinler Typenkalender.

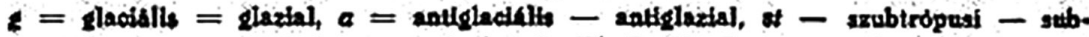

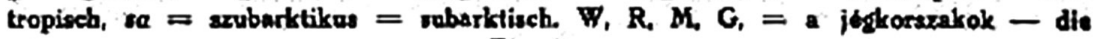
Etraeiten.

\begin{tabular}{|c|c|c|c|c|c|c|c|c|}
\hline $\begin{array}{l}\text { Ido } \\
\text { easer trekben }\end{array}$ & $\boldsymbol{T}$ & Tartam & $\begin{array}{c}\text { Ids } \\
\text { exer trekben }\end{array}$ & $T$ & Tartam & $\begin{array}{c}\text { IdD } \\
\text { ezer trekber }\end{array}$ & $T$ & Tertax \\
\hline $\begin{array}{c}\text { Zelt in } 1000 \\
\text { Jaben }\end{array}$ & $\boldsymbol{T}$ & Dawer & $\begin{array}{c}\text { Zoit in } 1000 \\
\text { Johren }\end{array}$ & $\boldsymbol{T}$ & Dewer & $\begin{array}{c}\text { Zoll in } 1000 \\
\text { Jahren }\end{array}$ & $T$ & Daxe \\
\hline $0.0-5.7$ & st & 5.7 & $215.8-221.2$ & a & 5.4 & $411.3-419.2$ & st & 7.9 \\
\hline $5.7-16.3$ & 2 & 10.6: & $221.2-226.5$ & sa & 5.3 & $419.2-1260$ & $\mathbf{a}$ & 68 \\
\hline $16.3-17.4$ & st & 1.1 & $226.5-237.5$ & R I & 11.0 & $126.0-128.5$ & sa & 25 \\
\hline $17.4-26.9$ & W III & 9.5 & $237.5-243.2$ & sa & 5.7 & $128.5-1388$ & M II & 10.3 \\
\hline $26.9-39.8$ & sa & 128 & $243.2-249.2$ & $\mathbf{a}$ & 6.0 & $438.8-147.8$ & ea & 90 \\
\hline $39.7-40.2$ & 1 & 0.5 & $249.2-261.1$ & st & 12.0 & $477.8-449.0$ & a & 1.2 \\
\hline $40.2-53.9$ & st & 13.7 & $261.2-263.7$ & \& & 2.5 & $499.0-460.7$ & st & 1t. 7 \\
\hline $53.9-57.0$ & $\mathbf{a}$ & 3,1 & $263.7-276.2$ & sa & 12.5 & $460.7-466.7$ & $\mathbf{a}$ & 6.0 \\
\hline $570-665$ & 6 & 9.5 & $276.2-284.7$ & 8 & 8.5 & $466.7-470.3$ & $=$ & 3.6 \\
\hline $665-77.7$ & W II & 11.2 & $284.7-2875$ & st & 2.8 & $470.3-0.7$ & M I & 10.4 \\
\hline T7.7-80.7 & 68 & 3.0 & $287.5-297.9$ & a. & 10.4 & $480.7-488.7$ & sa & 80 \\
\hline $80.7-88.2$ & 4 & 7.5 & $297.9-3040$ & st & 6.1 & $4887-4918$ & - & 3.1 \\
\hline $88.2-99.7$ & st & 11.5 & $3040-3080$ & 8 & 40 & $491.8-5029$ & at & 11.1 \\
\hline $99.7-100.2$ & $a$ & 0.5 & $308.0-318.3$ & sa & 10.3 & $502.9-508.0$ & $\mathbf{a}$ & 5.1 \\
\hline $100,2-110.6$ & sa & 10.4 & $318.3-3258$ & 8 & 7.5 & $508.0-517.5$ & $\mathrm{se}$ & 9.5 \\
\hline $1106-1220$ & WI & 11.4 & $325.8-328.7$ & st & 2.9 & $517.5-529.5$ & 8 & 120 \\
\hline $122.0-122.6$ & sa & 0.6 & $328.7-337.5$ & g & 8.8 & $529.5-531.5$ & st. & 20 \\
\hline $122.6-1338$ & a & 11.2 & $337.5-342.5$ & st & 5.0 & $531.5-5130$ & a & 11.5 \\
\hline $133.8-140.5$ & st & 6.7 & $342.5-346.3$ & $£$ & 3.8 & $543.0-545.8$ & st & 2.8 \\
\hline $140.5-146.0$ & 8 & 5.5 & $346.3-355.3$ & $8 a$ & 9.0 & $5458-553.7$ & G $\mathbf{I}$ & 7.9 \\
\hline $146.0-158.3$ & a & 12.3 & $355.3 \sim 362.6$ & 8 & 2.3 & $553.7-5642$ & 12 & 10.5 \\
\hline $158.3-160.0$ & $\varepsilon$ & 1.7 & $362,6-3647$ & st & 2.1 & $5642-567.3$ & 8 & 3,1 \\
\hline $160.0-170.2$ & st & 10.2 & $3647-3747$ & $a$ & 10.0 & $567.3-574.7$ & st & 7.4 \\
\hline $170.7-188.0$ & $\mathbf{a}$ & 9.8 & $374.7-382.5$ & st & 7.8 & $574.7-585.0$ & a & 10.3 \\
\hline $1800-1820$ & a & 2.0 & $392.5-3847$ & 8 & 2.2 & $585.0-586.2$ & st & 1.2 \\
\hline $1820-1928$ & R II & $10: 8$ & $3847-394.6$ & in & 9.9 & $\operatorname{seg} 2-\operatorname{ses} 1$ & G 1 & 8.9 \\
\hline $1928-201.7$ & 88 & 8.9 & $3946-1040$ & 8 & 9.4 & $595.1-600.0$ & $8 \mathbf{x}$ & $4 \%$ \\
\hline $201.7-203.8$ & $\mathbf{a}$ & 21 & $4040-405.7$ & sa & 1.7 & & & \\
\hline $203.8-215.8$ & st & 120 & $405.7-411.3$ & a & 56 & & & \\
\hline
\end{tabular}

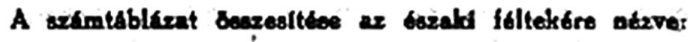

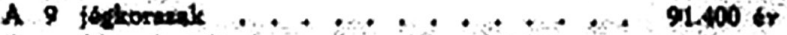

A meddó flacílisok . . 68,000 \&

Ax anticlacitiliat ..., . . 135.000.

A scubtropusl kilengselk . . 143.700 \&

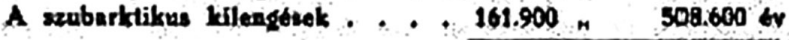

owareaces 600.000 is

3. ábra. Diluviális kalendárium (Bacsák, 1940, II. 66.) 
A felsorolt értékekből Bacsák György kézzel rajzolt kalendáriumot készített, amelyet elküldött Milutin Milankovićnak (4. ábra).

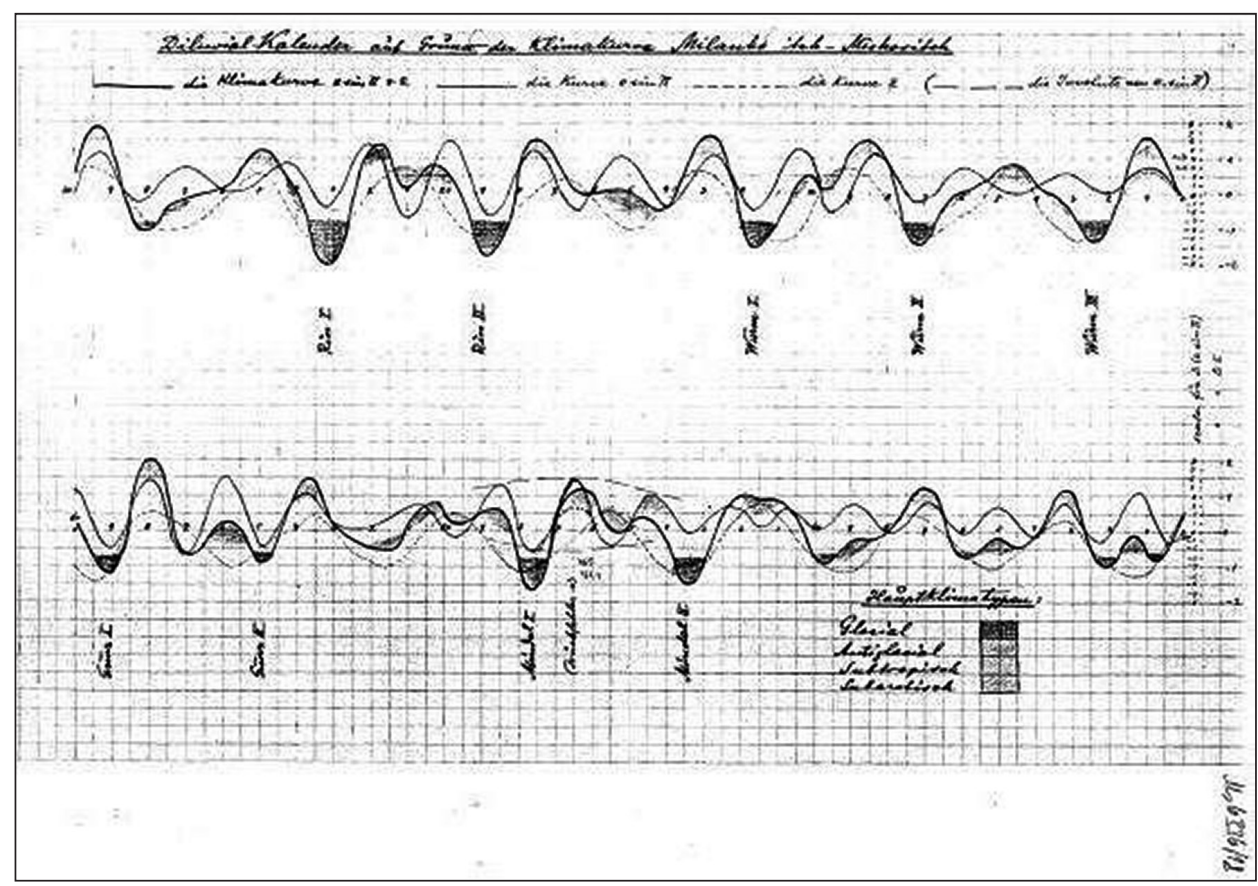

4. ábra. Kézzel rajzolt diluviális kalendárium Bacsák tollából

(Bacsák György levele Milutin Milankovićnak, 1938)

Bacsák György gondolata szerint a föbb klímatípusok közötti átmenetek $\pi$ miatt mindig rövidek.

„Ha úgy fogjuk fel a klímaváltozást, mint az $\varepsilon$ és e $(\sin \pi)$ hullámok interferenciáit, akkor egészen könnyü lenne a Mindel-Riss interglaciális hosszát meghatározni. Ebben az időszakban $\pi$ periódusa igen közel volt a 20000 évhez és még $\varepsilon$ is tartotta a 40000 éves periódusát..." (Bacsák, 1938). E folyamat 410000 éve zajlott le, ami szubarktikus klímát eredményezett, de ugyanez a folyamat játszódott le 370 000, 330000 és 290000 éve is. E két tényező tartotta magát a megfelelő intervallumhoz, tehát ezzel magyarázhatók a hosszú interglaciálisok.

Bacsák levelében kifejti, hogy „, ritmusa 0-290 000 és 410 000-600 000 évek között eltérő volt a 20000 évtől, ezért volt több jégkorszak és egészen rövid interglaciálisok. Hasonló módon magyarázzuk az interferenciát a második, a harma- 
dik jégkorszakokban is, és az interglaciálisokban is, a Riss I. és II., a Riss II. és a Würm I., és a Würm I. és II. között."

A levélben Bacsák kifejti, hogy a jégkorszakok és a jégkorszakközök nagy aszimmetriája a Günz- és Mindeli-dőszakokban az $e(\sin \pi)$ hosszú periódusának köszönhető, vagyis 20000 évtől eltérően itt 29000 évig tartott.

\section{ÉGHAJLATVÁLTOZÁS A TRÓPUSOKON}

Bacsák 1939 júliusában írt levelében („Gondolatok a trópusok...”) kifejti, hogy a jégkorszakok elsősorban a 45. és a 65. szélességi fok közötti területeket érintik, de vajon a trópusokat milyen mértékben érintette a jégkorszak?

Számba vette a hőmérséklet alakulásának kiszámításához használt egyenletet:

$$
Q=w s^{\circ}+\Delta w s \Delta \varepsilon \pm m(e \sin \pi)
$$

a $\Delta w s$ értékei alacsonyabbak, valamint $\Delta \varepsilon$ értékei a trópusokon nem játszanak szerepet, míg a $\Delta e(\sin \pi)$ önmagában a trópusokon nem képes jégkorszakot előidézni.

Bacsák levelében leírja, hogy egy normál évben a trópusokon két nyár és két tél osztozik 1/4-1/4 arányban. Váltakozásuk alapvetően a Nap nevezetes delelési pontjain, tavasszal, nyáron, ősszel és a decemberi nap-éj egyenlőséghez kapcsolódik.

Ha a megfigyelési pontunkat a jégkorszak idején az Egyenlítőtől a térítők felé haladva változtatjuk, akkor a térítók felé haladva el fog tủnni a négyes (kettő nyár és kettő tél) tagolás, és a féléves tagolás veszi át, vagyis tél és nyár hat-hat hónapos felosztása szerint.

Kutatásai ellenére Bacsák György megfigyeléseit nem tudta matematikai formába önteni, azonban óva intette követöit, hogy a hőmérséklet-süllyedés mértékét ne vegyék a jégkorszakokat érintő szélességi körökéhez hasonlónak.

\section{A MILANKOVIĆ-BACSÁK-CIKLUS LEHETŐSÉGE KISEBB ESEMÉNYEKBEN}

Ugyan glaciálisok és interglaciálisok a Föld történetében jelentős időszakot foglaltak el, azonban a kutatások kimutatták, hogy számos rendszertelenül megjelenő, legfeljebb néhány száz, de esetenként csak néhány évtizedig tartó gyors lefolyású klímaingadozás is bekövetkezett. Ezekre az éghajlati ingadozásokra az észak-atlanti jégfúrások és tengerfenéki gleccserhordalékok vizsgálatát végző kutatókról - Hartmut Heinrich, Willi Dansgaard, Hans Oeschger, valamint Gerard C. Bond - elnevezett eseményekként hivatkoznak. 
A pleisztocén ,jégkorszakokra” és különösen az utolsó, Würm-glaciális idején jellemző, rövid ideig tartó, egy-egy hasonló jellegü felmelegedéssel időben kapcsolódó, rövid átmeneti szakaszokkal határolt lehülési időszakokat Heinrich-eseménynek nevezzük.

Lehetséges okai között szerepel a hirtelen olvadás miatt letöredező gleccserjég, amely módosítja a „nagy óceáni szállítószalagot” (Czelnai, 1999), így ebből következően hirtelen, de rövid időre csökken a Föld északi féltekéjének hőmérséklete, mint például 12000 évvel ezelőtt (1. táblázat).

1. táblázat. A Heinrich-események időbeni lebontása

\begin{tabular}{|c|c|}
\hline Heinrich-esemény & $\begin{array}{c}\text { Ideje évezredekben } \\
\text { visszamenőleg (BP ezer évben) }\end{array}$ \\
\hline H0 & 12 \\
\hline H1 & $16-15$ \\
\hline H2 & $24-22$ \\
\hline H3 & $31-29$ \\
\hline H4 & $38-35$ \\
\hline H5 & 45 \\
\hline H6 & 60 \\
\hline
\end{tabular}

(Kordos, 2015; a szerző engedélyével)

A gyors hőmérséklet-csökkenést ugyancsak sebes hőmérséklet-emelkedés váltotta fel. Ezt nevezik Dansgaard-Oeschger-eseménynek. A hőmérséklet-növekedés Grönlandon $50-100$ év alatt megközelítöleg $10^{\circ} \mathrm{C}$-os gyors emelkedéssel járt, amit egy lassú, ám folyamatos lehülés követett (Rousseau-Sima, 2014).

A moréna üledékeiben végzett vizsgálatok nyolc olyan klímaszintet állapítottak meg, amelyek 1470 évenként ciklikusan ismétlődnek. Ezt nevezik Bond-eseménynek (Bond et al., 1999). E szabályos időközönként ismétlődő jelenségek lehülési klímaciklust mutatnak. Az utóbbi tízezer évben számos olyan esemény történt, amely meghatározta az emberiség történetének alakulását (2. táblázat).

A Bond-események okai még tisztázatlanok, azonban Vivien Gornitz és szerzőtársai (2009) felvetik, hogy a Föld orbitális Milanković-Bacsák-ciklusainak egyik összetevőjeként alakulhattak ki, amire a Nap sugárzási energiájának periodikus váltakozása is hatással lehetett. 
2. táblázat. A Bond-események és nevezetes történeti események

\begin{tabular}{|c|c|l|}
\hline Bond-esemény & $\begin{array}{c}\text { Ideje évezredekben } \\
\text { visszamenőleg (BP ezer évben) }\end{array}$ & \multicolumn{1}{|c|}{ Megnevezés } \\
\hline 0 & 0,5 & $\begin{array}{l}\text { az emberi történelem alakulásában jelentös } \\
\text { szerepet játszó kis jégkorszak } \\
\text { (Little Ice Age) }\end{array}$ \\
\hline 1 & 1,4 & vándorlások kora \\
\hline 2 & 2,8 & $\begin{array}{l}\text { Kr. e. korai első évezred, a késő bronzkori } \\
\text { kultúrák összeomlása }\end{array}$ \\
\hline 3 & 4,2 & az egyiptomi Óbirodalom \\
\hline 4 & 5,9 & neolitikum, atlantikum lecsengése ${ }^{1}$ \\
\hline 5 & 8,2 & „bibliai özönvizek” \\
\hline 6 & 9,4 & $\begin{array}{l}\text { gleccseraktivitás növekedése Norvégiában; } \\
\text { lehülés Kínában }\end{array}$ \\
\hline 7 & 10,3 & \\
\hline 8 & 11,1 & $\begin{array}{l}\text { átmeneti szakasz a fiatalabb driászból } \\
\text { a boreális szakaszba }\end{array}$ \\
\hline
\end{tabular}

(Kordos, 2015; a szerző engedélyével)

\section{ÖSSZEFOGLALÁS}

Ha a Föld jövőbeni éghajlatát akarjuk kiszámítani, akkor dinamikailag, ha nem is teljesen, de döntő mértékben értenünk kell a múlt éghajlatát (Major, 2006). Természetesen nem a teljes földtörténeti múlt éghajlatát, hanem az utóbbi néhány százezer évre vonatkozót. Azonban minél közelebb érünk napjaink éghajlatához, annál több tényezö játszott, akár külön-külön is meghatározó szerepet, például a Milanković-Bacsák-ciklus, a Nap aktivitásának ciklusai, a hegységképződés vagy kontinensvándorlás, az óceáni cirkuláció változásai, a bioszféra hatásai, a légkör összetételének különböző eredetű változásai, az emberi tevékenység fokozódó hatása. A sort még lehetne folytatni, de nem érnék a végére.

Az írás zárásaként szerepeljen itt Bacsák György (1940) mondata, miszerint:

„Az elméleti számítások tehát olyan jól vágnak a természet megfigyelés eredményeivel, hogy Milankovitch elméletében kételkedni nem lehet."

${ }^{1}$ Az antlantikum nem östörténeti fogalom, hanem sokkal inkább a biosztratigráfiai tagolás része. Ekkor a júliusi átlagos középhőmérséklet $17^{\circ} \mathrm{C}$ volt, amelyhez erősen csapadékos, ún. arid klíma társult. Erre az időpontra tehető az emberi hatás felerősödése a környezetben, például a mezőgazdaság háttérbe szorítja a növényi vegetációt. 
Bacsák állítása részben igaz, hiszen a megfigyelések részben igazolják Milanković elméletét, azonban a kutatók nem ismerik az éghajlatváltozás hatásmechanizmusát. Ugyanakkor nem mehetünk el azon tény mellett, hogy Milutin Milanković száz évvel ezelött kezdte el matematikai formába önteni az éghajlatváltozás csillagászati okait. Továbbá amellett sem mehetünk el szó nélkül, hogy a százötven éve (1870) született Bacsák György pontosítása nélkül Milanković elmélete csak egy lett volna a hiányos és nem pontos teóriák közül. A három hónap híján száz évet (1870-1970) megélt magyar polihisztornak pedig a szerb tudós elméletének javítása jelentette az akadémiai disszertációt nyolcvanöt évesen. Kölcsönösen egymásra voltak utalva, éppen ezért helyes a Milanković-Bacsák-elmélet elnevezés.

Bacsák György nem volt olyan elismert kutató, mint Eötvös Loránd, de az idei évben megérdemelne egy nagyszabású emlékkonferenciát születésének 150. és halálának 50. évfordulóján.

\section{IRODALOM}

Bacsák György levele Milutin Milankovićnak 1938-ban.

Bacsák György levele Milutin Milankovićnak 1939 júliusában

Bacsák Gy. (1940): Az interglaciális korszakok értelmezése I, II, III. Időjárás, 8-16., 62-69., 105108.

Bond G. - Showers, W. - Elliot, M. et al. (1999): The North Atlantic's 1-2 Kyr Climate Rhytm: Relation to Heinrich Events, Dansgaard/Oeschger Cycle and the Little Ice Age. In: Clark, P. - Webb, R. - Keigwin, L.: Mechanisms of Global Climate Change at Millennial Time Scales. (Geophysical Monograph Series) Washington DC., 112, 35-58. DOI: 10.1029/GM112p0035

Czelnai R. (1999): A világóceán. Budapest: Vince Kiadó

Gádoros M. (1970): Dr. Bacsák György. Karszt- és Barlangkutató Tájékoztató, 3. https://epa.oszk. hu/00400/00438/00026/pdf/EPA00438_KBT_1970_3.pdf

Gornitz, V. (ed.) (2009): Encyclopedia of Paleoclimatology and Ancient Environments. Encyclopedia of Earth Sciences Series. Dordrecht: Springer Science + Media B. V. 1047. https:// www.researchgate.net/publication/242697290_Encyclopedia_of_Paleoclimatology_and_Ancient_Environments

Heinrich, H. (1988): Origin and Consequences of Cyclic Ice Rafting in the Northeast Atlantic Ocean during the Past 130,000 Years. Quaternary Research, 29, 142-152.

Kordos L. (2015): Gyors klimatikus átmenetek az észak-atlanti területen. klímaszkeptikusok.hu, https://bit.ly/2UTqiIn

Major Gy. (2006): A Milanković-Bacsák-elmélet és az éghajlatváltozások. Légkör, 51, 20-23. http://owww.met.hu/legkor/legkor20060k.pdf

Rousseau, D. D. - Sima A. (2014): Abrupt Changes Recorded in Loess Sequences. Past Global Changes, 22, 2, 86-87. https://www.researchgate.net/publication/266476104_Abrupt_climate_changes_recorded_in_loess_sequences 